\title{
Polímeros has a new President of the Council Board and two newly appointed Associate Editors
}

2017 has been a special and productive year to Polímeros. Last October, 24 during the $14^{\text {th }}$ Congresso Brasileiro de Polímeros, which was held in Águas de Lindóia, SP, the members of the Council Board met and various important resolutions were taken. One of them was the appointment of the new President of the Council Board, Prof. Antonio Aprigio da Silva Curvelo, from Instituto de Química de São Carlos, Universidade de São Paulo, São Carlos, SP. He substitutes Prof. Marco-Aurelio de Paoli, from Instituto de Química, Universidade de Campinas, SP who is taking the Vice-Presidency of Associação Brasileira de Polímeros, ABPol. We acknowledge the great work Prof. de Paoli has done to this journal during his long staying and salute Prof. Curvelo to his new position. Another important decision was the appointment of two new members, Prof. Paula Moldenaers from University of Leuven, Belgium and Prof. Sadhan C. Jana from University of Akron, USA (below a short CV of both). They were at the same meeting, appointed as new international Associated Editors, joining Profs. Alain Dufresne (Grenoble INP/Pagora, France), José A. Covas (UMinho/IPC, Portugal) and Richard G. Weiss (GU/DeptChemistry, USA). We all welcome the new President and the members of the Associate Editors.

From January, 2017 the Council Board have approved the article-charge and it was promptly implemented to all accepted articles submitted to Polímeros since then. At the beginning a few authors of accepted articles disagreed with this helping fund. Today, just after 3 issues being published, all authors of accepted article did agree to contribute funding the journal. All members of the Council and Editorial team acknowledge this assertiveness, sign of a well-established community.

This year Polímeros has published 64 articles in all, 48 in its four standard issues. An extra issue containing the very last 16 accepted articles written in Portuguese was published in the beginning of this year. So far the journal had a submission of 86 articles, from which 40 were accepted. It is noteworthy to mention the increase of the submissions coming from the Brazilian states of Paraná and Paraíba. Submissions from abroad are also in continuous increase, especially from Colombia, India, Iran and Turkey. Terms like emulsion polymerization and biodegradable polymers were the most common search keywords used by the visitors of the journal's webpage.

For all that I alleged that 2017 has being a particularly productive year for Polímeros.

Sebastião V. Canevarolo Editor-in-Chief

\section{Short CV of the newly appointed President and Associate Editors of Polímeros.}

President of the Council Board
Prof. Antonio Aprigio S. Curvelo from Institute of Chemistry of São Carlos, University of São Paulo, São Carlos,
Brazil. His scientific work is dedicated to vegetal macromolecules, in particular dedicated to the separation of
macromolecules from lignocellulosic biomass by using organic solvents and fluids in the sub/supercritical states.
His work also includes the characterization of cellulose, hemicelluloses and lignins, and the production of micro-and
macromolecular derivatives and composite materials in a context of Biorefinery.

Associate Editor
Prof. Paula Moldenaers, from Department of Chemical Engineering, University of Leuven, Leuven, Belgium.
Her research interests focus on the rheology and morphology development in complex polymeric systems,
especially two-phase polymeric blends, filled polymers and biopolymeric systems. The research aims at providing a
science-based methodology for the processing of such complex fluids, developing and using advanced experimental
approaches which have resulted in unique experimental set-ups, data sets, characterization procedures, scaling
relations and morphological insight.

Associate Editor
Prof. Sadhan C. Jana from Department of Polymer Engineering, University of Akron, Akron, USA. His research
interests are mainly centered in understanding shape memory polymers and their nanocomposites and applications.
Also he is interested in the design of nanocomposites based on polyolefins, and the development of mechanisms
of nanoparticle-induced morphology in immiscible polymer systems.

